\title{
Anti-leishmanial and cytotoxic activities of extracts from three Pakistani plants
}

\author{
Kashif Iqbal $^{1 *}$, Javeid Iqbal ${ }^{1}$, Muhammad Umair ${ }^{2}$, Umar Farooq ${ }^{2}$, Muhammad \\ Mohsin lqbal ${ }^{2}$, Sumbal Qamar' ${ }^{2}$, Mehreen Bashir ${ }^{3}$ \\ ${ }^{1}$ Department of Pharmacology, Faculty of Pharmacy and Health Sciences, University of Balochistan, Quetta, ${ }^{2}$ Islam College of \\ Pharmacy, Sialkot, Punjab, ${ }^{3}$ Akson College of Pharmacy (MUST), Mirpur, AJK, Pakistan
}

*For correspondence: Email: kashifiqbal321@gmail.com; Tel: +92 3356951284

\begin{abstract}
Purpose: To evaluate the in vitro and in vivo anti-leishmanial and cytotoxic activities of extracts of different parts of Lawsonia Inermis, Morus nigra and Ziziphus mauritiana.

Methods: The methanol extracts of all three plant materials at concentrations of $10-100 \mu \mathrm{g} / \mathrm{mL}$ were tested for their in vitro anti-leishmanial effects on L. tropica KWH23 promastigotes for $24-48 \mathrm{~h}$, relative to negative control and amphotericin-B (standard drug). For in vivo anti-leishmanial activity, the extracts were tested against $L$. tropica-infected albino mice, while cytotoxicity was investigated against mammalian cells (lymphocytes).

Results: For Lawsonia Inermis leaves, mean inhibition of extracellular promastigotes at 10, 25, 50 and $100 \mu \mathrm{g} / \mathrm{mL}$ after $48 \mathrm{~h}$ were $98.2 \pm 0.06,98.75 \pm 1.09,99.31 \pm 0.00$ and $100.00 \pm 0.00 \%$, respectively. After 8 weeks, mean lesion size decreased from $0.8 \pm 0.2 \mathrm{~mm}$ to $0.3 \pm 0.1 \mathrm{~mm}(p<0.01)$, and cure at $150 \mathrm{mg} / \mathrm{kg}$ against intracellular amastigotes in albino mice was $97.02 \%(95 \% \mathrm{Cl}=96.14-98.10) . / C_{50}$ for Lawsonia inermis leaf extract was $12.22 \mu \mathrm{g} / \mathrm{mL}(95 \% \mathrm{Cl}=11.54-13.84)$ against lymphocytes.

Conclusion: The results obtained in this study show that Lawsonia Inermis leaf is safe and possesses potent anti-leishmanial activity.
\end{abstract}

Keywords: Leishmania tropica, Lawsonia inermis, Morus Nigra, Ziziphus Mauritiana, Anti-leishmania, Amastigotes, Lymphocytes

Tropical Journal of Pharmaceutical Research is indexed by Science Citation Index (SciSearch), Scopus, International Pharmaceutical Abstract, Chemical Abstracts, Embase, Index Copernicus, EBSCO, African Index Medicus, JournalSeek, Journal Citation Reports/Science Edition, Directory of Open Access Journals (DOAJ), African Journal Online, Bioline International, Open-J-Gate and Pharmacy Abstracts

\section{INTRODUCTION}

Lawsonia inermis is commonly known as Henna (Family Lythraceae). It is native to Northern Africa and South-Western Asia, and is cultivated in many tropical and sub-tropical regions. Different parts of the plant, especially the leaves, flowers, stem bark and roots have been used as traditional medicine for years. Phytochemical composition of the plant include flavonoids, coumarins, alkyl phenones, terpenes (volatile terpenes, non-volatile terpenes), aliphatic hydrocarbons, and alkaloids, all of which possess a variety of pharmacological activities, including antioxidant, antiviral and anti-parasitic [1-5].

Morus nigra (local name: Shahtoot) belongs to the family Moraceae. It is widely distributed in Asia, Africa, America (North and South Areas) and Europe. Its root, twigs, bark and fruits contain phenolic compounds used to treat asthma. Studies have reported that the plant is rich in isoprenylated flavonoids, triterpenes and saponins, which have antioxidant, antibacterial and anticancer activities [6-8]. Ziziphus 
mauritiana (local name: Ber) is a fruit tree which belongs to family Rhamnaceae. Its fruit has been used as a medicament for wound and ulcer healing, and as a sedative. Different parts of the plant exhibit pharmacological activities due to the presence of alkaloids, triterpenoids, and saponins, which are reported to have antimicrobial and antioxidant activities [9-13].

In this study, anti-leishmanial activities of different parts of Lawsonia inermis, Morus nigra and Ziziphus mauritiana were were investigated against Leishmania tropica promastigotes and amastigotes. The cytotoxic effects of the extracts on mammalian lymphocytes were also studied.

\section{EXPERIMENTAL}

\section{Chemicals}

Fetal bovine serum (FBS), dimethyl sulfoxide (DMSO), RPMI-1640 medium, amphotericin B, penicillin, streptomycin, formic acid, analytical grade solvents (ethanol, methanol and acetone) were purchased from Sigma-Aldrich (St. Louis, MO, USA). Water used for analysis was purified by deionization and $0.22 \mu \mathrm{m}$ membrane filtration (Millipore, Billerica, MA, USA).

\section{Collection of plant material and preparation of crude extract}

Lawsonia inermis leaves (LIL), stem bark (LISB) and seed (LIS); Morus nigra leaves (MNL) and stem bark (MNSB); and Ziziphus mauritiana leaves (ZML) and stem bark (ZMSB) were collected from the territory of Dera Ismail Khan, Khyber Pakhtunkhwa (KPK), Pakistan between August and September 2015. The plants were identified by Dr Siraj-ud-Din, Department of Botany, University of Peshawar, and voucher specimens [Bot, 200101 (pup), 200102 (pup), and 200106 (pup)] were deposited in the Herbarium of the Department. Each plant material was washed with distilled water before shade-drying at temperatures below $35^{\circ} \mathrm{C}$. The dried material was ground to powder and stored in a cool dark place until use. Crude extract was obtained by soaking $1 \mathrm{~kg}$ of powdered material in 2 liters of methanol for 1 week, with regular stirring. The extract was first filtered through muslin cloth, and then through Whatman filter paper no. 41. The filtrate was concentrated under reduced pressure at $46^{\circ} \mathrm{C}$ in a rotary evaporator, and weighed.

\section{Phytochemical screening}

The extracts were screened for phytochemical composition in accordance with the TLC method of Stahl [14] by Benedict reagent (flavonoid and coumarin test), Dragendorff's reagent (alkaloid test), benzidine (phenol test), amide test and Kedde reagent (glycoside test).

\section{In vitro anti-leishmanial activity}

In vitro anti-leishmanial activities of LIL, LISB, LIS, MNL, MNSB, ZML, and ZMSB extracts were tested with clinical isolate of Leishmania tropica promastigotes (KWH23, now Pakistani clinically isolated strain, UOP) according to growth inhibition assay described by lqbal et al [15]. Promastigotes of Leishmania tropica were cultured in RPMI-1640 medium containing $10 \%$ fetal bovine serum, $200 \mathrm{U} / \mathrm{mL}$ of penicillin, and $0.2 \mathrm{mg} / \mathrm{mL}$ of streptomycin. The parasites were cultured at $26{ }^{\circ} \mathrm{C}$ for 4 days in BOD incubator (Gallenkamp, size 1, UK), after which the promastigotes were harvested in sterile tubes. Viable cell count was done by transferring 5 - 10 $\mu \mathrm{l}$ of the promastigotes to a haemocytometer (Reichert, New York, U.S.A), and enumerating them under upright microscope (CX31, Olympus, Tokyo, Japan). The number of promastigotes (viable cell count, Vw) was calculated as in Eq 1.

Vw $($ live cells $/ \mathrm{ml})=\mathrm{C} / \mathrm{L}) \mathrm{D} 10^{4}$

where $C$ is number of live cells counted, $L$ the number of large corner squares counted, and $D$ is the dilution factor used

The harvested promastigotes were subsequently centrifuged at $2000 \mathrm{rpm}$ for $10 \mathrm{~min}$ at $4{ }^{\circ} \mathrm{C}$; the supernatant was removed, and the pellet reconstituted in fresh RPMI-1640 medium containing $10 \%$ FBS to obtain a concentration of $1.4 \times 10^{6}$ promastigotes $/ \mathrm{mL}$ in the required volume $(10 \mathrm{~mL})$. This was dispensed $(10 \mu \mathrm{l})$, using multiple pipettes, into 96-well culture plate containing the plant extracts in separate wells at three different concentrations $(10,25,50$ and $100 \mu \mathrm{g} / \mathrm{mL}$ ), mixed and left in BOD incubator at $26{ }^{\circ} \mathrm{C}$ for two days. Thereafter, the promastigotes were counted under upright microscope (lens 40x) at 24 and $48 \mathrm{~h}$ in a haemocytometer. The in vitro anti-leishmania test was performed in triplicate and the mean percentage inhibition of parasite was obtained.

\section{In vivo anti-leishmania assay}

Male BALB/c mice (20-32 g; aged 6-8 weeks) were used. The mice were supplied by Department of Pharmacology Animal Center, University of Peshawar, KPK, Pakistan. Leishmania tropica $\mathrm{KWH} 23$ promastigotes were cultured in RPMI-1640 medium containing $10 \%$ fetal bovine serum, $200 \mathrm{U} / \mathrm{mL}$ penicillin and 0.2 
$\mathrm{mg} / \mathrm{mL}$ streptomycin. The parasite was cultured and multiplied at $26{ }^{\circ} \mathrm{C}$ for 4 days in BOD incubator and harvested. The harvested promastigotes were taken in sterile tubes and counted in a haemocytometer under upright microscope. Then the promastigotes were centrifuged at $2000 \mathrm{rpm}$ for $10 \mathrm{~min}$ at $4{ }^{\circ} \mathrm{C}$. The supernatant was discarded, while the pellet was diluted to $10 \mathrm{~mL}$ with fresh RPMI-1640 medium containing $10 \%$ FBS. This was injected $(10 \mu \mathrm{L})$ intraperitoneally into the cardiac cavity of BALB/C mice. Development of lesion was measured weekly with dial micrometer during the infection period. Infection was well established and lesions were clearly visible to the naked eye after 36 days. Treatment with the extracts started at this stage.

9 groups $(n=6)$ of BALB/c mice were used, out of which 7 groups comprised extract-treated, 1 group was standard drug, and 1 group was negative control. The extracts were dissolved in DMSO and administered separately to groups I, II, III, IV, V, VI and VII at a dose of $30 \mathrm{mg} / \mathrm{kg}$ for 5 days (each group received one extract only). Amphotericin was used as standard drug at a dose of $15 \mathrm{mg} / \mathrm{kg}$. No drug agent was used in group VIII (negative control). The drug was administered five times to each mice at 3-day intervals and result was recorded regularly. Dial micrometer was used to note the differences between sizes of the lesion in infected and uninfected mice weekly. Before and after treatment, needle aspirations of samples were taken from infection/lesion areas [15]. For detection of amastigotes under the light microscope, Giemsa stain was used under oil immersion. On 48th, 60th and 90th days postinfection, $60 \mathrm{mg}$ of tissue sample was taken from lesion zones for biopsy. Each sample was smeared on slides stained with Giemsa and examined under light microscope.

\section{Ethical statement}

This study was approved by Animal and Ethics Committee, Faculty of Pharmacy and Health Sciences, University of Balochistan (UOB), Quetta (approval ref. no. 093/FOPHS/UOB). The animals were maintained in accordance with UOB, Quetta Policy and international guidelines on the care and use of laboratory animals [16]. Standard diet and water were given ad libitum to the animals during the experiments.

\section{Cytotoxicity test}

Fresh blood (10 $\mathrm{mL}$ ) was taken in BD Vacutainer K2E (EDTA) from a healthy volunteer as a source of mammalian cells (lymphocytes) for cytotoxic analysis of extracts. The lymphocytes were isloated according to the method outlined by Bøyum [15,17]. Extracts were added at concentrations of $100,50,25$ and $10 \mu \mathrm{g} / \mathrm{mL}$ in DMSO. Amphotericin (25 $\mu \mathrm{g} / \mathrm{mL})$ served as reference drug, while negative control was Leishmania tropica KWH23 promastigotes. Using a multipipette, equal concentration of promastigotes $\left(1.4 \times 10^{6}\right.$ promastigotes $\left./ \mathrm{mL}\right)$ was put in each well of a 12-well culture plate, which was then incubated at $26{ }^{\circ} \mathrm{C}$ for $48 \mathrm{~h}$. Viable lymphocytes and promastigotes were counted under light microscope (lens 40x) at 24 and $48 \mathrm{~h}$. The cytotoxic test was carried out in triplicate, and $\mathrm{IC}_{50}$ values were determined.

\section{Data analysis}

Inhibition (\%) of parasite growth was expressed as mean $\pm S D(n=3)$. Cytotoxic activity was expressed as $50 \%$ inhibitory concentration $\left(\mathrm{IC}_{50}\right)$ and analysed by non-linear regression analysis. For in vivo assays, mean lesion size $(\mathrm{mm})$ and percentage cure rate were analysed with GraphPad Prism 5 software (GraphPad software, San Diego, CA). $P<0.05$ was taken as significant.

\section{RESULTS}

\section{Phytochemical profile of plant extracts}

Methanolic extract of Morus nigra stem bark exhibited highest extraction yield of $30.35 \%$ while the lowest yield of $9.32 \%$ was seen in leaves of Lawsonia inermis. The yields for all extracts are shown in Table 1.

Table 1: Yield of methanol plant extracts

\begin{tabular}{lll}
\hline Plant Extract & Yield (\%) & Phytochemical profile \\
\hline LIL & 9.32 & Tannins, Flavonoids, Coumarins, Terpenes \\
LISB & 25.11 & \\
LIS & 11.13 & \\
MNL & 26.89 & Triterpenes, Flavonoids, Coumarins, Saponins \\
MNSB & 30.35 & \\
ZML & 10.15 & Terpenoids, Flavonoids, Alkaloids \\
ZMSB & 18.15 & \\
\hline
\end{tabular}




\section{In vitro antileishmanial activity}

The extracts produced inhibition ranging between 22 and 66.1 at $10 \mu \mathrm{g} / \mathrm{mL}$, while at $100 \mu \mathrm{g} / \mathrm{mL}$, inhibition ranged between 39.06 and $93 \%$ (Table 2). At $48 \mathrm{~h}$, inhibition ranged between 40.09 and 98.2 at $10 \mu \mathrm{g} / \mathrm{mL}$, and between 60.01 and $100 \%$ at $100 \mu \mathrm{g} / \mathrm{mL}$. Methanol extract of Lawsonia inermis leaves and seed exhibited highest activities $(100 \%)$ at $100 \mu \mathrm{g} / \mathrm{mL}$. Lawsonia inermis stem bark showed promising inhibitory activity, with $98 \%$ at $100 \mu \mathrm{g} / \mathrm{mL}$. In comparison with negative control (NC), except for 24th hour analysis of Morus nigra (stem bark and leaves) and Ziziphus mauritiana (leaves and stem bark) with parasitic inhibition ranging between 39.06 and $50.09 \%$ at $100 \mu \mathrm{g} / \mathrm{mL}$, all extracts showed promising parasite inhibition against $L$. tropica. Lawsonia inermis showed the most significant results, ranging between 90 and $93 \%$ antileishmanial activity after $24 \mathrm{~h}$ at $100 \mu \mathrm{g} / \mathrm{mL}$.

\section{In vivo anti-leishmanial activity}

In vivo anti-leishmanial activities of LIL, LISB, LIS,MNL, MNSB, ZML, and ZMSB in albino mice infected with $0.02 \mathrm{~mL}$ clinically isolated $L$. tropica KWH23 having $1.4 \times 10^{6}$ promastigotes via intraperitoneal route, showed promising results after 36-120 days (Table 3). In six (6) sample groups, mean lesion size of mice decreased significantly from $0.5 \pm 0.51 \mathrm{~mm}$ to $0.3 \pm 0.9 \mathrm{~mm}$ after treatment with the plant extracts, but the mean lesion size of the negative group reached $1.5 \pm 0.5 \mathrm{~mm}(p>0.05)$, whereas in amphotericin-B group, it decreased from $0.95 \pm$ $0.6 \mathrm{~mm}$ to $0.35 \pm 0.6 \mathrm{~mm}$, at the end of $8^{\text {th }}$ week.

Table 2: In vitro anti-leishmanial activity of plant extracts

\begin{tabular}{|c|c|c|c|}
\hline \multirow[t]{2}{*}{ Sample } & \multirow{2}{*}{$\begin{array}{c}\text { Sample concentration } \\
(\mu \mathrm{g} / \mathrm{mL})\end{array}$} & \multicolumn{2}{|c|}{ Inhibition (\%) } \\
\hline & & $24 \mathrm{~h}$ & $48 \mathrm{~h}$ \\
\hline \multirow[t]{4}{*}{ LIL } & 10 & $66.1 \pm 0.02$ & $98.2 \pm 0.06$ \\
\hline & 25 & $78.68 \pm 0.03$ & $98.75 \pm 1.09$ \\
\hline & 50 & $85.35 \pm 0.10$ & $99.31 \pm 0.00$ \\
\hline & 100 & $90.00 \pm 0.34$ & $100.00 \pm 0.00$ \\
\hline \multirow[t]{4}{*}{ LISB } & 10 & $55.10 \pm 0.70$ & $95.11 \pm 0.00$ \\
\hline & 25 & $62.00 \pm 0.20$ & $96.03 \pm 0.57$ \\
\hline & 50 & $70.07 \pm 0.40$ & $98.01 \pm 1.00$ \\
\hline & 100 & $80.00 \pm 0.20$ & $98.96 \pm 0.00$ \\
\hline \multirow[t]{4}{*}{ LIS } & 10 & $80.01 \pm 0.40$ & $95.04 \pm 0.10$ \\
\hline & 25 & $84.00 \pm 0.30$ & $97.37 \pm 0.00$ \\
\hline & 50 & $88.05 \pm 0.20$ & $98.95 \pm 0.37$ \\
\hline & 100 & $93.00 \pm 0.20$ & $100.00 \pm 0.00$ \\
\hline \multirow[t]{4}{*}{ MNL } & 10 & $34.00 \pm 0.10$ & $50.55 \pm 0.18$ \\
\hline & 25 & $38.56 \pm 0.40$ & $55.90 \pm 0.07$ \\
\hline & 50 & $45.01 \pm 0.04$ & $60.23 \pm 0.24$ \\
\hline & 100 & $50.09 \pm 0.06$ & $65.98 \pm 0.96$ \\
\hline \multirow[t]{4}{*}{ MNSB } & 10 & $22.00 \pm 0.00$ & $40.09 \pm 0.06$ \\
\hline & 25 & $32.09 \pm 0.10$ & $42.33 \pm 1.09$ \\
\hline & 50 & $35.11 \pm 0.70$ & $45.98 \pm 0.00$ \\
\hline & 100 & $40.23 \pm 0.40$ & $47.78 \pm 0.87$ \\
\hline \multirow[t]{4}{*}{ ZML } & 10 & $29.19 \pm 0.20$ & $60.09 \pm 0.37$ \\
\hline & 25 & $35.07 \pm 0.05$ & $65.67 \pm 1.15$ \\
\hline & 50 & $39.10 \pm 0.20$ & $67.54 \pm 1.27$ \\
\hline & 100 & $45.68 \pm 0.40$ & $70.03 \pm 1.59$ \\
\hline \multirow[t]{4}{*}{ ZMSB } & 10 & $23.00 \pm 0.90$ & $55.99 \pm 0.00$ \\
\hline & 25 & $27.07 \pm 0.08$ & $57.22 \pm 0.17$ \\
\hline & 50 & $32.16 \pm 0.09$ & $58.33 \pm 0.00$ \\
\hline & 100 & $39.06 \pm 0.08$ & $60.01 \pm 1.48$ \\
\hline \multirow[t]{4}{*}{ Amp } & 10 & $55.12 \pm 0.16$ & $94.09 \pm 0.06$ \\
\hline & 25 & $67.34 \pm 0.09$ & $97.67 \pm 1.09$ \\
\hline & 50 & $76.45 \pm 0.10$ & $98.62 \pm 0.00$ \\
\hline & 100 & $81.78 \pm 0.07$ & $99.55 \pm 0.57$ \\
\hline \multirow[t]{4}{*}{$\mathrm{NC}$} & 10 & $0.00 \pm 0.00$ & $0.00 \pm 0.00$ \\
\hline & 25 & $0.00 \pm 0.00$ & $0.00 \pm 0.00$ \\
\hline & 50 & $0.00 \pm 0.00$ & $0.00 \pm 0.00$ \\
\hline & 100 & $0.00 \pm 0.00$ & $0.00 \pm 0.00$ \\
\hline
\end{tabular}


Table 3: In vivo anti-leishmanial activities of plant extracts

\begin{tabular}{|c|c|c|c|c|c|c|}
\hline Sample & $\begin{array}{l}\text { Dosing } \\
\text { regimen }^{\text {a,b }} \\
\text { (for } 5 \\
\text { days) }\end{array}$ & $\begin{array}{l}\text { Mean lesion } \\
(\mathrm{mm}) \text { pre- } \\
\text { treatment }\end{array}$ & $\begin{array}{l}\text { Mean lesion } \\
\text { (mm) post- } \\
\text { treatment } \\
\text { (after } 8 \text { weeks) }\end{array}$ & $\begin{array}{l}\% \text { Cure rate } \\
\text { (with } 95 \% \\
\text { Confidence } \\
\text { intervals, } \mathrm{Cl} \text { ) }\end{array}$ & $\begin{array}{l}\text { No: of mice } \\
\text { cured/No: of } \\
\text { mice Infected }\end{array}$ & $\begin{array}{l}\text { Mean } \\
\text { survival } \\
\text { time } \\
\text { (days) }\end{array}$ \\
\hline LIL & $30 \mathrm{mg} / \mathrm{kg}$ & $0.8 \pm 0.2$ & $0.3 \pm 0.1$ & $\begin{array}{c}97.022 \\
(96.136-98.097)\end{array}$ & $6 / 6$ & $\geq 60$ \\
\hline LISB & $30 \mathrm{mg} / \mathrm{kg}$ & $0.6 \pm 0.3$ & $0.4 \pm 0.7$ & $\begin{array}{c}85.27 \\
(84.205-86.84)\end{array}$ & $5 / 6$ & $\geq 60$ \\
\hline LIS & $30 \mathrm{mg} / \mathrm{kg}$ & $0.5 \pm 0.8$ & $0.3 \pm 0.9$ & $\begin{array}{c}90.51 \\
(89.61-91.89)\end{array}$ & $6 / 6$ & $\geq 60$ \\
\hline MNL & $30 \mathrm{mg} / \mathrm{kg}$ & $0.85 \pm 0.1$ & $0.71 \pm 0.3$ & $\begin{array}{c}60.194 \\
(61.002-63.671)\end{array}$ & $3 / 6$ & $\geq 60$ \\
\hline ZML & $30 \mathrm{mg} / \mathrm{kg}$ & $0.72 \pm 0.2$ & $0.60 \pm 0.2$ & $\begin{array}{c}75.02 \\
(74.96-76.39)\end{array}$ & $4 / 6$ & $\geq 60$ \\
\hline ZMSB & $30 \mathrm{mg} / \mathrm{kg}$ & $0.65 \pm 0.1$ & $0.5 \pm 0.51$ & $\begin{array}{c}70.151 \\
(69.487-72.941)\end{array}$ & $3 / 6$ & $\geq 60$ \\
\hline Amp & $15 \mathrm{mg} / \mathrm{kg}$ & $0.95 \pm 0.6$ & $0.35 \pm 0.6$ & $\begin{array}{c}95.00 \\
(94.583-96.02)\end{array}$ & $6 / 6$ & $\geq 60$ \\
\hline $\mathrm{NC}$ & $30 \mathrm{mg} / \mathrm{kg}$ & $0.7 \pm 0.5$ & $1.5 \pm 0.5$ & 0.000 & $0 / 6$ & $\geq 0$ \\
\hline
\end{tabular}

Data are mean lesion size $(\mathrm{mm}) \pm \mathrm{SD}$

Mice that received methanol extract of Morus nigra leaves, Ziziphus mauritiana leaves and Ziziphus mauritiana stem bark had mean lesion size of $0.71 \pm 0.3 \mathrm{~mm}, 0.60 \pm 0.2 \mathrm{~mm}$ and $0.5 \pm$ $0.51 \mathrm{~mm}$, respectively; with corresponding $\%$ cure of $60.194 \%, 75.02 \%$ and $70.151 \%$ respectively after 8 weeks of treatment. The average mean lesion size observed for the mice treated with Lawsonia inermis leaves, stem bark and seed extracts decreased to $0.3 \pm 0.1,0.4 \pm$ 0.7 , and $0.3 \pm 0.9 \mathrm{~mm}$ respectively, corresponding to a cure of $97.022,85.27$ and $90.51 \%$, respectively. It is evident that from the results that Lawsonia inermis leaves and seed exhibited potent in vivo anti-leishmanial activities against $L$. tropica.

Table 4: Cytotoxic Effect of Plant extract. Data represent $I_{50}(\mu \mathrm{g} / \mathrm{ml})$ with $95 \%$ confidence limit

\begin{tabular}{ll}
\hline Sample & Inhibition $(\boldsymbol{\mu g} / \mathbf{m l}, \mathbf{C l})$ \\
\hline LIL & $12.215(11.543-13.841)$ \\
LISB & $14.752(13.286-14.751)$ \\
LIS & $15.312(14.013-15.992)$ \\
MNL & $>100$ \\
ZML & IC $_{50}(\mu \mathrm{g} / \mathrm{ml}) 95 \%$ \\
ZMSB & $>100$ \\
\hline
\end{tabular}

\section{Cytotoxic effects}

LIL, LISB, LIS, MNL, ZML, and ZMSB showed moderate in vitro cytotoxic effects against lymphocytes after 24-48 h (Table 4). Methanol extract of Morus nigra leaves and Ziziphus mauritiana leaves and stem bark showed highest cytotoxic activities at a concentration of more than $100 \mu \mathrm{g} / \mathrm{mL}$. Lowest cytotoxic activity was observed when Lawsonia inermis leaves, stem bark and seed extract were exposed to
Iymphocytes, with $I_{50}$ values of $12.215,14.752$ and $15.312 \mu \mathrm{g} / \mathrm{mL}$, respectively.

\section{DISCUSSION}

In this work, methanol was selected as a solvent for extraction due to its polar nature. All parts of Lawsonia inermis showed in vitro inhibition ranging between $98.96 \pm 0.00$ and $100 \pm 0.00$ at $100 \mu \mathrm{g} / \mathrm{ml}$ concentration $(p<0.01)$ after 48 hours. This is in agreement with anti-leishmanial activity of the plant as reported previously [18]. It is known that Lawsonia inermis possesses secondary metabolites such as flavonoids, tannins, coumarins, terpenes, saponins and alkaloids $[2,6,10]$. These phytochemicals might be responsible for the observed antileishmanial and cytotoxic activities against $L$. tropica.

Lawsonia inermis possessed significant in vitro and in vivo activity against $L$. tropica promastigotes at levels higher than those of Morus nigra, Ziziphus muaritiana and Amphotericin-B. Most albino mice were cured within 120 days of infection, when extract of Lawsonia inermis was given, with mean lesion size decreased up to $0.3 \pm 0.1 \mathrm{~mm}$ after the 8th week. This curative effect may be due to extractinduced death of promastigotes/amastigotes through inhibition of metabolic pathways of $L$. tropica strains. The cytotoxic effect of Lawsonia inermis leaves was lower ( $\mathrm{IC}_{50}$ value: 12.215 $\mu \mathrm{g} / \mathrm{mL}$ ) when compared with other tested plant extracts.

However the observed cytotoxic effect of Lawsonia inermis is consistent with previous reports on its cytotoxicity against Hep G2 and MCF - 7 [19]. 
Although different biological activities related to these plants have been reported in literature, this is the first time that a comprehensive study in respect of in vitro, in vivo and cytotoxic activities of Lawsonia inermis (leaves, stem bark and seed), Morus nigra leaves, and Ziziphus mauritiana (leaves and stem bark) are reported against $L$. tropica and mammalian cells.

\section{CONCLUSION}

The findings of this study indicate that the leaves of Lawsonia inermis possess potent antileishmanial properties against $L$. tropica, probably due to the presence of tannins, flavonoids, coumarins and terpenes. This plant offers some promise as a source of newer and safer anti-leishmanial drugs.

\section{DECLARATIONS}

\section{Acknowledgement}

The authors would like to thank Prof Dr Fazal Subhan of Department of Pharmacy, University of Peshawar, Peshawar, Pakistan for providing the albino mice and other technical support.

\section{Conflict of Interest}

No conflict of interest associated with this work.

\section{Contribution of Authors}

The authors declare that this work was done by the authors named in this article and all liabilities pertaining to claims relating to the content of this article will be borne by them.

\section{REFERENCES}

1. Liou JR, ElShazly M, Du YC, Tseng CN, Hwang TL, Chuang YL, Hsu YM, Hsieh PW, Wu CC, Chen SL, et al., 1,5-Diphenylpent-3-en-1-ynes and methyl naphthalene carboxylates from Lawsonia inermis and their anti-inflammatory activity. Phytochemistry 2013; 88: 67-73.

2. Semwal RB, Semwal DK, Combrinck S, Cartwright-Jones C, Viljoen A. Lawsonia Inermis L. (henna): Ethnobotanical, Phytochemical and pharmacological aspects. J Ethnopharmacol 2014; 155: 80-103.

3. Hsouna $A B$, Trigui $M$, Culioli $G$, Blache $Y$, Jaoua $S$. Antioxidant's constituents from Lawsonia Inermis leaves: Isolation, structure elucidation and antioxidative capacity. Food Chem 2011; 125: 193-200.
4. Khan MM, Ali A, Jain DC, Bhakuni RS, Zaim M, Thakur RS. Occurrence of some antiviral sterols in Artemisia annua. Plant Sci 1991; 75(2): 161-165.

5. Okpeton T, Yolou S, Gleye C, Roblot F, Loiseau $P$, Bories C, Grellier $P$, Frappier $F$, Laurens $A$, Hocquemiller $R$ Antiparasitic activities of medicinal plants used in Ivory Coast. J Ethanopharmacol 2004; 90(1): 91-97.

6. Mazimba O, Majinda RR, Motihanka D. Antioxidant and antibacterial constituents from Morus Nigra. Afr J Pharm Pharmacol 2011; 5(6): 751-754.

7. Arfan M, Khan R, Rybarczk A, Amarowicz R. Antioxidant activity of Mulberry fruit extracts. Int J Mol Sci 2012; 13: 2472-2480.

8. Vitali A, Ferrari F, Monache GD, Bombardelli E, Botta B. Synthesis and biosynthesis of Isocordoin. Planta Med 2001; 67: 475-477.

9. Ademir FM, Graciela M, Vinicius I. The Alkaloids: Chemistry and Biology. Academic Press, London, 2009; 67: $79-141$

10. Lee S, Min B, Lee C, Kim K, Kho Y. Cytotoxic triterpenoids from the fruits of Zizyphus jujube. Planta Med 2003; 69: 1051-1054

11. Yoshikawa K, Shimono N, Arihara S. Antisweet substances jujuboa saponins I-III from Ziziphus jujuba revised structure of ziziphin. Tetrahedron Lett 1991; 32:7059-7062.

12. Kayser O, Arndt SK. Antimicrobial activity of some Ziziphus species used in traditional medicine. Pharma Pharmacolo Lett 2000; 10: 38-40.

13. Ndhlala AR, Chitindingu K, Mupure $C$, Murenje T, Ndhlala $F$, Benhura MA. Antioxidant properties of methanolic extracts from Diospyros mespiliformis (jackal berry), Flacourtia indica (Batoka plum), Uapaca kirkiana (wild loquat) and Ziziphus mauritiana (yellow berry) fruits. Int J Food Sci Tech 2008; 43: 284-288.

14. Stahl E. Thin Layer Chromatography 2nd Edition Springer-Verlag Berlin, Heidelberg, GmbH. 1969; 854905

15. Iqbal K, lqbal J, Afreen MS. Comparative Study on Antileishmanial and Cytotoxic activity of Lawsonia Inermis bark and Aloe Vera leaves. Int $\mathrm{J}$ Biol Pharm Allied Sci 2016, 5(6), 1490-1500.

16. Bøyum A. Isolation of lymphocytes, granulocytes and macrophages. Scand J Immunol 1976; 5: 9-15.

17. Serakta M, Djerrou Z, Mansour-Djaalab H, KahloucheRiachi F, Hamimed S, Trifa W, Belkhiri A, Edikra N, Pacha YH., Antileishmanial activity of some plants growing in Algeria: Juglans regia, Lawsonia Inermis and salvia officinalis. Afr J Tradit Complement Altern med 2013; 10 (3): 427-430.

18. National Research Council of The National Academy of Sciences. Guide for the Care and Use of Laboratory Animals: 8th edn. Washington, D.C.: The National Academies Press; 2010.

19. Endrini S, Rahmat A, Ismail P, Taufiq-Yap YH. Comparing of the cytotoxicity properties and mechanism of Lawsonia Inermis and Strobilanthes crispus extract

Trop J Pharm Res, October 2016; 15(10): 2118 
lqbal et al

against several cancer cell lines. J Med Sci 2007; 7(7):

1098-1102.

Trop J Pharm Res, October 2016; 15(10): 2119 